\title{
Pengaruh Pemberian Kombinasi Jus Bayam dan Jambu Biji terhadap Kadar Hemoglobin pada Ibu Hamil di Wilayah Kerja Puskesmas Balowerti Kota Kediri
}

\author{
Putri Wahyu Wigati ${ }^{1}$, Nikmatul Firdaus ${ }^{1}$ \\ ${ }^{1}$ Fakultas Ilmu Kesehatan Universitas Kadiri \\ Corresponding author: Putri Wahyu Wigati (puthree.2806@gmail.com) \\ Received 31 August 2018; Accepted 6 September 2018; Published 24 September 2018
}

\begin{abstract}
Anemia is a condition of insufficient Hemoglobin $(\mathrm{Hb})$, in the blood which is primarily caused by a deficiency of nutrients (especially iron) needed for the formation of Hb. While anemia in pregnancy is a caused by iron diffusion and acute bleeding, even the distance between the two interact. The purpose of this study is to determine the effect of combination of spinach and Guava juice to increase Hemoglobin levels in pregnant women The study design using the Experiment Design approaches the one-group pre-post test design. The populations in this study were all pregnant women in work Area Health Center of Kediri, a large sample of 16 respondents to the sampling technique using simple random sampling. The primary data collection using observation sheets and SOP and the results were analyzed by $T$ test .Before administering a combination of spinach and Guava juice average hemoglobin value 10.475 , and after the administration of a combination of spinach and Guava juice average hemoglobin value of 11.438 was obtained $p$-value $=0.000$ then the p-value $<0.05$ Points means $\mathrm{H} 0$ rejected $\mathrm{H} 1$ accepted, so the conclusion there is influence between consuming combination of spinach and Guava juice to increase $\mathrm{Hb}$ levels of pregnant women For the respondents expected combination of spinach and Guava juice can be used as an alternative medicine to increase $\mathrm{Hb}$ levels.
\end{abstract}

Keywords: Combination of spinach and guava juice, $\mathrm{Hb}$ level, pregnant women

Copyright @ 2018 STIKes Surya Mitra Husada

All rights reserved.

This is an open-acces article distributed under the terms of the Creative Commons Attribution-ShareAlike 4.0 International License.

\section{PENDAHULUAN}

Kehamilan adalah suatu karunia yang begitu didambakan bagi seorang wanita. Selama masa kehamilan biasanya wanita banyak mengalami banyak perubahan dan berbagai macam keluahan, oleh karena itu harus memperhatikan dan menjaga buah kehamilannya dengan baik. Proses kehamilan diawali dengan bersatunya sel telur dengan sel sperma, kemudian dilanjutkan dengan pembelahan dan implantasi pada rahim (Baety,2011). 
Selama kehamilan banyak faktor resiko yang dapat menyebakan terjadinya komplikasi pada ibu hamil antara lain terjadinya anemia pada ibu hamil, perdarahan, berat badan abnormal dan terkena penyakit infeksi (Depkes RI, 2012). Salah satu yang harus diwaspadai pada saat kehamilan adalah anemia pada kehamilan. Anemia dalam kehamilan adalah kondisi ibu dengan kadar hemoglobin di bawah $11 \mathrm{gr} \%$ pada trimester I dan III atau kadar $\mathrm{Hb}<10,5 \mathrm{gr} \%$ pada trimester II (Saifuddin, 2009).

Hasil Riset Kesehatan Dasar tahun 2013, prevalensi anemia pada ibu hamil di indonesia sebesar 37,1\% (Kemenkes RI, 2013). Di Jawa Timur angka ibu hamil dengan anemia sebanyak 49,9\% dan kota Surabaya sebesar 12,65. Dinas Kesehatan Kota Kediri melaporkan kejadian anemia selama tahun 2014 cukup tinggi yaitu dari 250 ibu hamil yang menderita anemia pada triwulan I sebesar 18,4\%, Triwulan II sebesar16\% dan triwulan III sebesar 27,6\%( Dinkes Kota Kediri, 2015). Dalam pembangunan jangka menengah (RJPKM 2014-2019) pemerintah mempunyai target menurunkan prevalensi anemia ibu hamil dari $37,1 \%$ menjadi $28 \%$.

Berdasrkan pengambilam data survey awal di Puskesmas Balowerti. Jumlah ibu hamil trimester I yaitu $34(33,3 \%)$ ibu hamil dengan anemia 5 orang, jumlah ibu hamil trimestr II yaitu 30 $(29,4 \%)$ ibu hamil dengan anemia 7 orang, dan jumlah ibu hamil trimester III yaitu 38 ibu hamil dengan anemia 7 orang. Dari di atas dapat di Interprestasikan bahwa data tersebut terdapat 19 $(18,6 \%)$ ibu hamil dengan kadar $\mathrm{Hb}$ di bawah $<11 \mathrm{gr} \%$ dan yang tidak mengalami anemia atau kadar $\mathrm{Hb}>11 \mathrm{gr} \%$ sebesar $83(81,3 \%)$ ibu hamil. Hal ini menunjukkan bahwa masih adanya angka kejadian anemia pada ibu hamil di Wilayah Kerja Puskesmas Balowerti. Penyebab kadar hemoglobin secara praktis pada ibu hamil adalah menurunnya kadar hemoglobin dalam darah. Hemoglobin memiliki peranan penting dalam transportasi oksigen ke dalam jaringan tubuh. Selama masa kehamilan akan terjadi sebuah peningkatan volume darah, hal inilah yang bisa membuat hemoglobin dalam darah menurun. Sedangkan tuntutan dari perkembangan janin akan membuat kebutuhan zat besi dalam tubuh menjadi meningkat. (Saifuddin ,2011).

Dampak mikro yang timbul akibat kurangnya kadar hemoglobin : keletihan, malas dan lemas, sesak nafas, jantung berdebar, mual, wajah pucat, penurunan daya sistem imun, mata pucat, sakit kepala dan pingsan serta dampak makro akibat kurangnya kadar hemoglobin adalah keguguran (abortus), kelahiran premature dan imatur, persalinan yang lama akibat kelelahan otot rahim didalam berkontraksi (inersia uteri), gangguan kontraksi uterus pasca persalinan (atonia uteri), syok, infeksi, baik saat persalinan maupun pasca persalinan, berat badan bayi lahir rendah (Wiknjosastro,2010). Upaya untuk meningkatkan kadar hemoglobin ibu hamil selain pemberian tablet besi, dapat dikombiinasikan dengan terapi kompementer yang berasal dari herbal, dua diantaranya bayam merah dan jambu biji. Suplemen tablet Fe diberikan selama hamil sebanyak 90 tablet dengan bersamaan mengkonsumsi Zat Besi dan Vitamin C (sayrifudin 2009). Kandungan Zat Besi banyak terdapat pada bayam dan kandungan Vitamin $\mathrm{C}$ banyak terdapat pada buah jambu biji. Vitamin $\mathrm{C}$ yang tinggi berfungsi sebagai antioksidan dan meningkatkan daya tahan tubuh, selain itu Vitamin C juga mampu meningkatkan penyerapan zat besi dalam lambung kemudian akan meningkatkan kadar hemoglobin pada darah. Buah jambu biji merupakan tanaman sayuran buah yang sangat dibutuhkan oleh manusia untuk memenuhi kebutuhan hidupnya. Hal ini disebabkan karena kandungan gizi buah jambu biji yang terdiri dari vitamin dan mineral sangat berguna untuk mempertahankan kesehatan dan mencegah penyakit. Buah jambu biji memiliki senyawa likopin dan vitamin $\mathrm{C}$ yang dapat membantu penyerapan zat besi dengan baik. Sehingga perlu di coba dalam penelitian untuk membuktikan fakta yang ada.

Tujuan dari penelitian ini adalah untuk mengidentifikasi kadar hemoglobin ibu hamil sebelum diberikan kombinasi jus bayam dan jambu biji, Mengidentifikasi kadar hemooglobin ibu hamil sesudah di berikan kombinasi jus bayam dan jambu biji serta menganalisis kadar hemoglobin ibu hamil sebelum dan sesudah diberikan kombinasi jus bayam dan jambu biji.

\section{BAHAN DAN METODE}

Desain Penelitian yang digunakan adalah pre eksperiment dengan pendekatan pretest posttest one group design. Jumlah sampel yang digunakan adalah 16 orang yang memenuhi criteria inklusi dan eksklusi. Teknik sampling yang digunakan adalah simple random sampling. Analisi data yang digunakan uji statistic paired $\mathrm{T}$ test yang sebelumnya dilakukan uji normalitas sebaran data. 


\section{HASIL DAN PEMBAHASAN}

Kadar $\mathrm{Hb}$ Sebelum Pemberian Kombinasi Jus Bayam dan Jambu Biji Pada Ibu Hamil di Wilayah Kerja Puskesmas Balowerti Kota Kediri

Tabel 1 Distribusi Frekuensi Kadar Hemoglobin Sebelum diberikan Kombinasi Jus Bayam dan Jambu Biji Pada Ibu Hamil di Wilayah Kerja Puskesmas Balowerti Kota Kediri

\begin{tabular}{lccccc}
\hline Variabel & $\mathrm{N}$ & Min & Max & Mean & SD \\
\hline HB Sebelum & 16 & 8,2 & 13,0 & 10,475 & 1,345 \\
\hline
\end{tabular}

Berdasarkan Tabel 1 dapat diintrepertasikan bahwa rata - rata Kadar Hemoglobin pada Ibu hamil sebelum diberikan Kombinasi Jus Bayam dan Jambu Biji Pada Ibu Hamil di Wilayah Kerja Puskesmas Balowerti Kota Kediri 10,475

Tabel 2 Distribusi Frekuensi Kadar Hemoglobin Sesudah diberikan Kombinasi Jus Bayam dan Jambu Biji Pada Ibu Hamil di Wilayah Kerja Puskesmas Balowerti Kota Kediri

\begin{tabular}{llllcc}
\hline Variabel & $\mathrm{N}$ & Min & Max & Mean & SD \\
\hline Hb Sesudah & 16 & 10,0 & 13,3 & 11,438 & 9.570 \\
\hline
\end{tabular}

Berdasarkan Tabel 2 dapat diintrepertasikan bahwa rata - rata Kadar Hemoglobin pada Ibu hamil sesudah diberikan Kombinasi Jus Bayam dan Jambu Biji Pada Ibu Hamil di Wilayah Kerja Puskesmas Balowerti Kota Kediri 11, 438

Tabel 3 Pengaruh Pemberian Kombinasi Jus Bayam dan Jambu biji terhadap peningkatan kadar hemoglobin pada ibu hamil di wilayah kerja Puskesmas Balowerti Kota Kediri Tahun 2018

\begin{tabular}{lccc}
\hline Kadar HB & Mean & SD & SE \\
\hline sebelum & 10,47 & $.1,354$ & 3385 \\
\hline sesudah & 11.43 & 9,570 & 2392 \\
\hline \multicolumn{5}{c}{$\rho$ value $=0.00$} & $\alpha=0,05$ \\
\hline
\end{tabular}

Berdasarkan tabel 3 Menunjukan bahwa jumlah responden 16, dengan mean kadar hemoglobin sebelum pemberian kombinasi jus Bayam dan Jambu Biji adalah 10,47 gr\%. Pada pengukuran sesudah pemberian kombinasi jus Bayam dan Jambu Biji didapatkan nilai mean 11,43 gr $\%$. Tingkat kepercayaan $95 \%$ hasil uji statistik mendapatkan nilai $\rho$ value 0,000 maka disimpulkan bahwa ada pengaruh pemberian kombinasi jus Bayam dan Jambu Biji terhadap peningkatan kadar $\mathrm{Hb}$ pada ibu hamil.

\section{PEMBAHASAN}

Berdasrakan tabel ada pengaruh signifikan pemberian kombinasi jus Bayam dan Jambu Biji terhadap peningkatan kadar $\mathrm{Hb}$ ibu hamil dengan $\square$ value (sig.) $0.000<\alpha(0,05)$. Hasil tersebut di dasarkan pada rata-rata kadar $\mathrm{Hb}$ meningkat sesudah pemberian kombinasi jus Bayam dan Jambu Biji . Artinya pemberian kombinasi jus Bayam dan Jambu Biji dapat meningkatkan kadar Hb ibu hamil.

Terapi kombinasi pemberian jus bayam dan Jambu Biji ini dapat menjadi alternatif bagi ibu hamil yang tidak mau mengkonsumsi tablet suplemen besi karena efek samping seperti mual dapat digantikan dengan terapi jus ini karena telah terbukti dapat meningkatkan kadar hemoglobin pada ibu hamil . Dari uraian di atas maka dapat dikemukakan bahwa terapi ini dapat berpengaruh terhadap peningkatan kadar hemoglobin ibu hamil. Kadar hemoglobin ibu hamil merupakan indikator penilaian anemia. Zat besi secara alamiah diperoleh dari makanan, dapat berasal dari hewan maupun tumbuhan. Zat besi dalam Bayam dikombinasikan dengan kandungan vitamin c dalam Jambu Biji disajikan dalam bentuk minuman (jus), sehingga membantu proses 
penyerapan zat besi dengan baik. Zat besi akan membentuk hemoglobin dan mempertahankan sel-sel darah merah bagi ibu hamil. Kebutuhan zat besi penting sekali bagi ibu hamil karena berfungsi untuk memenuhi masa sel darah merah janin, tali pusat dan plasenta, serta menggantikan darah yang hilang saat persalinan. Dengan demikian terapi zat besi ini dapat dikombinasikan dengan terapi komplementer yang berasal dari herbal (Bayam dan Jambu Biji ) karena terbukti dapat meningkatkan produksi sel darah merah sehingga kadar hemoglobin juga meningkat.

\section{PENUTUP}

\section{Simpulan dan Saran}

Kesimpulan dari penelitian ini adalah Kadar $\mathrm{Hb}$ pada ibu hamil sebelum diberi kombinasi jus bayam dan jambu biji Rata-rata Sebesar 10,5 gr\% dan sesudah diberi kombinasi jus bayam dan jambu biji terdapat peningkatan Rata-rata Sebesar 11,4 gr\%. Hasil Uji statistic menunjukkan bahwa ada pengaruh pemberian kombinasi jus bayam dan jambu biji terhadap kadar $\mathrm{Hb}$ ibu hamil. Sehingga rekomendasi yang bias disampaikan adalah kombinasi jus bayam dan jambu biji dapat digunakan sebagai alternatif pengobatan alamiah pada ibu hamil yang mengalami anemia.

\section{DAFTAR PUSTAKA}

A.N.S, Thomas. (2008). Tanaman Obat Tradisional, Yogyakarta: KANISUS (Anggota IKAPI)

Arikunto, Suharsini. (2010). Prosedur Penelitian Suatu Pendekatan Praktik. Jakarta: Rineka Cipta

Apriadji, Wied Harry. (2007). Makanan Enak Untuk Hidup Sehat, Bahagia dan Awet Muda. Jakarta: Gramedia Pustaka Utama

Efendi, Ferry. (2009). Keperawatan Kesehatan Komunitas Teori dan Praktek dalam Keperawatan, Jakarta: Salemba Medika

Fakultas kedokteran Universitas padjajaran. (1983). Obstetri Fisiologis, Bandung: Elemen

Hariana, Arief, H. Drs. (2000). Tanaman Obat dan Khasiatnya, Bandung: Penebar Swadaya

Handayani, Wiwik, S.Kep. (2008). Asuhan Keperawatan Pada Klien Dengan Gangguan Hematologi, Jakarta: Salemba Medika

Hidayat, Alimul Aziz. (2008). Keterampilan Dasar praktik Klinik Untuk Kebidanan, Jakarta: Salemba Medika

Khomsan, Ali, MS. Prof. Dr. Ir. (2011). Terapi Jus Untuk Rematik dan Asam Urat, Bandung: Sehat Keluarga

Kusmiyati, Yuni, S. T. dkk (2009). Perawatan Ibu Hamil, Yogyakarta: FitramayaManuaba Ida Bagus Gede. Prof,dr dkk (2010), Ilmu Kebidanan, Penyakit Kandungan, dan KB. Jakarta: EGC

Novie. (2013). pengaruh terapi kombinasi jus bayam dan jambu biji terhadap peningkatan kadar hemoglobin pada ibu hamil anemia $\{$ Diakses tanggal 3 Februari 2018\}

Nursalam. (2008). Konsep dan Penerapan Metodologi Penelitian Ilmu Keperawatan, Jakarta: Salemba Medika

Pearce, Evelyn C. (2006). Anatomi dan Fisiologi untuk Paramedis, Jakarta: Gramedia

Syafrudin, SKM, M.Kes. (2009). Kebidanan Komunitas, Jakarta: EGC

Yusnaini. (2013). pengaruh konsumsi jambu biji terhadap perubahan kadar hemoglobin pada ibu hamil\{ Diakses tanggal 3 Februari 2015\} 